Fecha de recepción: marzo 2020 Fecha de aceptación: abril 2020 Versión final: junio 2020

\section{Distinguishing the Female Protagonist in Douglas Sirk's All That Heaven Allows, Rainer Werner Fassbinder's Ali: Fear Eats the Soul and Todd Haynes' Far From Heaven}

Kyle Heger ${ }^{(1)}$

\begin{abstract}
When a movie is remade the primary story changes in order to reflect the social norms of a new audience. Ali: Fear Eats the Soul (1974) and Far From Heaven (2002) are replicas of the original film All That Heaven Allows from 1955. Each film tackles different issues with the female as the protagonist. Social class, race and homosexuality are at the core of these three films. In this paper, I will discuss all three films and interject how the heroine discovers herself and why she needs to evolve. As each heroine finds herself, she strives to break the monotony that society has constructed for her and by breaking free she discovers what she has been looking for on her own terms. Societal structures barricade our protagonist by creating obstacles for her to move through, like class differences, racial bigotry and love. The female's journey will be looked at through a critical analysis of each film including its production design, score and lighting. Feminist film theory will help us understand how these generations look at female characters on film. In the next decade, this film may be told through a completely different filter based on the societal norms of what that generation is facing.
\end{abstract}

Keywords: Melodrama - film - female protagonist - film criticism - Laura Mulvey Douglas Sirk - Rainer Werner Fassbinder - Todd Haynes.

[Abstracts in spanish and portuguese on the pages 214-215]

${ }^{(1)}$ Kyle Heger is a Columbia College alumnus (2019) in the field of Cultural Studies with an emphasis in media and popular culture. He was part of the Chicago Feminist Film Festival (2017-2019). Kyle created a lecture series about The Salta Trilogy of Lucrecia Martel and served on the board of The Art House. Kyle is pursuing a Masters in Visual and Critical Studies at School of the Art Institute of Chicago (SAIC). 


\section{Introduction}

Barbara Klinger, author of the book Melodrama and Meaning: History, Culture and the films of Douglas Sirk, writes that: "Melodrama's inherent commitment to extreme emotion, dramatic crescendoes, and irrational twists of fate portrayed through reversals and coincidences yields a sense of exaggeration now that may alter the original desired effect" (145). This idea of the melodrama allows for re-envisioning to occur, giving an opportunity of growth to happen for the characters on screen. As a melodramatic film becomes memorable and cemented in time, we have to be able to detach intentions from the movie-makers to what the audience sees as important and significant.

In Douglas Sirk's All That Heaven Allows, Rainer Werner Fassbinder's Ali: Fear Eats the Soul, and Todd Haynes' Far From Heaven, our female protagonists move through the film dealing with love and loss, personal growth and political differences. These women stand out for their resilience against societal norms and showcase the love that they have for the men on screen, even if it means sacrificing something for themselves. This paper will discuss the female protagonist through a critical lens bridging film analysis and film criticism. The use of alienation in all three films helps each story function within the decade that they were made. While alienation and film critique are important, we as the audience have a visceral response seeing the entrapment and separation through the director's use of color, production design and mise-en-scene.

A critical reading of each film will showcase the female's strengths and weaknesses, with each film presenting differing cases for each side. The web that these directors weave showcases female empowerment while also showing a defeated woman as well. How are these male directors making sure the female on screen is carefully crafted, allowing for her own personal power to shimmer and shine through? When attaching the idea of alienation, can the female move through her own situations and possess truth on film? Does the audience allow for these women's stories to become timeless, or do they only survive in the decade from which they were created?

\section{All That Heaven Allows}

In 1955's All That Heaven Allows, the film begins and visually establishes a nostalgic pastiche that contemporary audiences would find reminiscent of a simpler time. Nostalgia is a tool used by creatives to present a simple message that becomes timeless. This nostalgic force is presented in many forms of media, from print advertising to televised commercials to films and television series that re-hash the period piecefilm or create a series that looks back at a time that either does or does not need to be romanticized. In the case of All That Heaven Allows, Sirk's filmmaking presents a nod to Norman Rockwell's timeless Americana paintings and a picturesque-20th Century outlook on nature and rural beauty. Sirk's work in establishing a beautiful rich tapestry of color and setting is seen through the director's use of lavish romanticized music set against a suburban Utopia to create a moment audiences long for. This romanticized 
world also is re-imagined by Todd Haynes in the beginning and ending of his 2002 film Far From Heaven.

Douglas Sirk's All That Heaven Allows is a film that focuses on our protagonist, Cary Scott, finding her place in suburbia after the loss of her husband. Cary, played by Jane Wyman, is an affluent widow who begins a new friendship with her late husbands hired-help Ron Kirby, played by Rock Hudson. Ron's feelings for Cary move from kinship to love. Cary initially pushes him away because she is uncertain of what she wants. As Cary begins to understand how important Ron is to her and how much she enjoys his philosophy on life, her life seems shallow and unfulfilled.

Douglas Sirk brings two women on screen to show the difference of freedom through appearance. Sara, played by Agnes Moorhead, is first seen wearing a dazzling and bold blue sweater-skirt set paired with a lilac blouse and a contrasting green kerchief tied around her neck. Instead of warm colors Cary is wearing a cement-grey cardiganbuttoned suit and skirt with a light-grey blouse underneath. The colors each woman chooses to wear reflects their personal freedom at the start of the film. Cary's masculinegrey cardigan and skirt outfit is meant to reflect the man of the house, yet the white pearl necklace is a nod to her femininity. Sara is out and about running errands when she visits Cary. By showcasing the suburban woman in two different colors, the audience sees the freedom and care-free attitude of Sara's life compared to a confined entrapment that has lingered with Cary all of these years. As Cary deals with being a widow we see her in both masculine and feminine attire throughout the film. Some of Cary's clothing reflects her character's subdued and conservative nature when she is wearing neutrals that cover her up. When she starts wearing bolder colors and more revealing outfits, many of the men either lustfully objectify her or shame her for appearing too available. Consequently she ends up choosing less feminine colors and sticking with neutrals that keep her in the background. Douglas Sirk's technicolor achievements in the 1950s use color to heighten architectural spaces and spaces where his characters would live, especially in films like Imitation of Life (1959) and in Magnificent Obsession (1954). Douglas Sirk breathes life not just into his characters but also into the setting where these characters gather together in town squares, in living rooms or in country clubs.

The mix of colors between Cary and Sara are representative of where they both belong in the societal framework of class and stature, and we can see this in how they present body language in the country club scene. The country club is shown with a mixture of blue tones all throughout the space. Sirk's use of color is often sighted as a staple to the 1950s technicolor melodramas that he was directing at the time. Against the soft blues, we see all the women draped in color and exquisite fabrics to play as a counter-part to the lighting and production design in the room. Cary is draped in a beautiful rose-red dress, Sara is wearing a luxurious cerulean blue that showcases her bust allowing for her character to be open and relaxed, open to having a bit of fun with the guests. Cary wears her pearls to try to fit in and to showcase her wealth. However, the costume jewelry that Sara wears overshadows Cary. The lighting in the room helps to sell this idea where Sara is in front of a teal light and Cary is still in the shadows against a darker grey-colored blue.

To keep Cary stuck in her home, she is bombarded with the idea of television as a means to escape her uneventful life. Mr. Weeks is the TV salesman that catches Cary as she's 
about to step out and go see Ron. Cary, while basking in the joys of love and what love has to offer, loses control of her home from her own family. Her children start to take over without her knowledge and consent. This is first seen with her daughter, Kay Scott, showing off her engagement ring. The day that Freddie proposed to Kay was the day that Cary left Ron in order to please her daughter. The second is having her son, Ned Scott, selling the house because "it's too big with one person in it, with taxes and all". Cary should be able to stand up for herself and not lose control of her home, yet the insistent controlling nature of Ned upsets Cary. This causes Cary to have tension headaches. Sara's disapproval of Ron and his line of work is demonstrated in Sara's attitude towards Cary's housecleaner, another blue collar worker.

The feeling of entrapment and being stuck at home seems to be what the children want for Cary. This is why Ned's gift to Cary is a television set. Ned, along with Mr. Weeks, presents the table model to Cary stating "All you have to do is turn that dial and you have all the company you want right there on the screen". The camera moves to show her confined reflection in the television screen as Mr. Weeks says: "Drama, Comedy, life's parade at your fingertips." The two kids keep tabs on Cary while not really knowing who their mother actually is and they assume that Cary has no life outside of being a wife and a mother. Cary's reflection is truly herself, a detached realization that presents an emptiness that suffocates and alienates her. No one within her family or her social circles truly knows her, causing her reflection to show herself imprisoned. We see the imprisoning through the vanity table in her bedroom and the sheen from the music rack of the piano in the living room. The TV set that Ned and Mr. Weeks bring in at Christmas time is the third item in her home that cements the isolation within her own home; Cary's reflection in her possessions both the vanity table and the piano suggest that there is more to life but the reflection imprisons her to only what possessions are beside her. Ron's group of friends while free-spirited and open minded do not know Cary but still are inviting and willing to get to know her. The country club paints the high society as shallow, full of gossip and adultery while the lobster bake with Ron's set of friends is bohemian and unbiased and they accepted Cary for Cary.

\section{Ali: Fear Eats the Soul}

Rainer Werner Fassbinder's 1974 film Ali: Fear Eats the Soul retells the story that Douglas Sirk presented to the audience nineteen years earlier. Fassbinder's admiration of Sirk came alive in the 1970s and remained an influence throughout his career. By adapting Sirk's visual language, Fassbinder began to create dense and robust films that showcase the harsh and cold reality of German life.

Ali, on a work visa from Morocco, is a mechanic in an auto shop. He finds a place for himself to call home with his Arab buddies at the bar where we first see him. Emmi, a middle aged white woman of German descent who works a domestic job cleaning apartments, comes to the bar where Ali and his Arab buddies are drinking and enjoying each others company. Emmi soon enjoys the conversation and connection that they 
have created, and we see them both become infatuated and interested in each other. Throughout the film, Fassbinder's nods to nationalism and societal politics is still an issue, and he used both Emmi and Ali's relationship as a way to show how fractured Germany is at the time.

In the opening scene, Emmi walks into a bar to get out of the pouring rain. She is met with looming stares from all the patrons. The smart technique of isolating the patrons from Emmi allows for both worlds to exist awkwardly until the bartender goes over to Emmi, breaking the invisible tension between both parties. Emmi asks for a Coke from the female bartender. Fassbinder's stagnant cinematography presents the audience with feelings of discrimination and disgust from the bar patrons, presented in visible and uncomfortable silence until Ali goes over to talk to Emmi. The camera, placed as if it were a regular in the bar, offers the audience no real sense of understanding who she is or who these bar patrons are until she strikes up a conversation with Ali. After they share a dance at the bar, Ali walks Emmi home. The journey of these characters blossoms into a relationship, and soon marriage. Emmi and Ali quickly realize how racist and nationalist viewpoints from the people in Munich try to tarnish their relationship.

Emmi's life, once as a widow, becomes harder when she decides to marry Ali. Her family reacts negatively to her decision to marry as her son violently kicks in her TV set, and she soon becomes aware of the nationalist and racist reactions from her family. Emmi's neighbors first are standoffish and childlike when it comes to Ali being in Emmi's apartment, so it takes a while for the two main women to be comfortable with him staying with Emmi. The two women come over to talk with Emmi and soon become infatuated with Ali as the two women chat with him; he flexes his muscles and makes the two women happy. The two women act in a frenzy over his body and strength. These two women seem to accept him then, but it took them to see only one-dimension of his character and what Ali possesses to even be recognized. The two women never got to know him but still touch him as if he is a creature from another world. Ali, aware of the way in which people treat him because of his color, his body and people's ignorant views, also is shocked by how he is fetishized or made to feel diminished as a foreigner.

Emmi and Ali share a heartbreaking scene together in a gorgeous restaurant courtyard. Appearing isolated from the public while out in public, Emmi breaks down in front of Ali. Our opening shot creates a sense of compact isolation in a beautiful world. The courtyard is filled with yellow-slatted chairs on cool white steel sitting among vibrant green trees. Emmi, to Ali, says: "Sometimes I wish I were all alone with you in the world with nobody around us". What we see in the times they spend alone out in the world is alienation and being shunned from society. Emmi breaks down during the courtyard scene, and her collapse into Ali's hands comes from all the weight of the world against their relationship. Emmi breaking down in front of Ali presents the struggle to stay positive in the world she lives in, keeping her emotionally exhausted as she goes about her daily routines between work and home. One of the strongest correlations in Fassbinder's film to Sirk's All That Heaven Allows comes from the final scene where Emmi goes to see Ali in the hospital after Ali has an ulcerated stomach attack. While Emmi will do whatever she can to help Ali recover from his stomach pain, we don't see the Hollywood ending that we did in Sirk's film. The ending of All That Heaven Allows shows Cary standing by Ron's side, letting the 
audience see that she still cares for Ron and she wants to stay by his side because she is finally "home." The ending in Ali: Fear Eats the Soul shows Emmi coming to see Ali in the hospital, but in the final scene neither talk. The music in Douglas Sirk's film allows for the woman's film to have an air of anticipation that is dressed in romanticized love for the man by her side.

In Fassbinder's film, Emmi's sadness is coated with uncertainty which leaves the two characters in limbo. The stark, cold grey that the hospital window presents in the scene also adds a layer of uncertainty and a stifling of emotions. The restraining of emotions is an exact correlation to Mulvey in her book Visual and Other Pleasures. In the chapter entitled Notes on Sirk and Melodrama, she writes: "melodramatic characters act out contradiction to varying degrees and gradually face impossible resolutions and probably defeats. However, the implications and poignancy of a particular narrative cannot be evoked wholly by limited characters with restricted dramatic functions - they do not fully grasp the forces they are up against or their own instinctive behaviour" (41). Mulvey is implying that within the melodrama, we see the function of the secondary characters who aren't on screen for long still acting out feelings of disdain for the protagonist, in this case the disdain would be towards Emmi and even with Cary in All That Heaven Allows. In Fassbinder's film, Emmi is looked down on for marrying a foreign worker and we see this in how Fassbinder frames Emmi within spaces of the home and even when she is out. In the scene when Emmi goes to Ali's work at the mechanic shop, we see the men joking in her face calling her 'Ali's grandmother from Morocco'. The contempt and sadness that permeates from the characters in the scene allows for the secondary characters to be sadistic while we see the main characters sadness stifled because each have to keep up appearances for the public; both Ali and Emmi are faced with an impossible resolution for their relationship, with a community uncertain of how to accept their progressive relationship.

The big difference between Sirk's story and Fassbinder's re-imagining of Sirk's story is the political climate of Germany versus the societal politics within Sirk's telling of suburbia. As written in German Culture Through Film: An Introduction to German Cinema, "Bavarian conservatism makes the city (Munich) ideal for portraying the constant struggle between past and present" (127). In contrast, Sirk's melodramatic films are presented in sunny suburbia using a breakdown of the family dynamic from ideals of class, love and societal rights and wrongs. This can be seen in All That Heaven Allows, as well as Magnificent Obsession (1954) and Written On The Wind (1957), all directed by Douglas Sirk.

Ali and Emmi each respond differently from being ostracized from society. Ali responds very differently because he is both foreign and still grasping the ideals of a society that stands on nationalist viewpoints. While the story of Ali and Emmi's relationship within the film looks bleak and harsh at times, we also realize that a filmmaker can give the story so much weight in distributing the need for the audience to respond and feel an attachment or detachment to the characters on screen.

In Ali: Fear Eats The Soul, the position of the camera does two things for the audience watching at home. Fassbinder presents a cold reality that is shown through interiors and in how characters are positioned throughout the storyline and in scenes throughout the film. Fassbinder's visual language is presented with silence. Silence is often more 
deafening than a loud reaction. This silence is seen when the female protagonist is shown as alienated from her surroundings, which creates tension between her and the society she encounters. This can be seen in the opening scene of the film and to when Emmi invites her family to meet newly married Ali. Fassbinder's cinematic painting, using the static shots of people staring or shooting the film around bleak architecture, offers a way of looking at how people would stop and stare at Emmi and Ali move through their lives while others are cemented to the ground not allowing themselves to move forward. Ali Fear Eats The Soul, while the warmth that Emmi and Ali offer to the film makes the film tender and sweet whilst at times, presents not just alienation from people ons screen but also through how isolation can be presented within the home.

Steven Peacock writes: "Fassbinder's aesthetic is rife with impulses pushing in different directions: putative opposites that somehow mesh...Fassbinder fills everyday settings with artifice and illusion to get to life's truths. His films comprise an immersion in the plastic arts of cinema, celebrating the mediums potentialities even as they pull it apart" (81). Fassbinder's understanding of confined spaces on film lets the audience feel how exhausting it is to be any of these characters. The apartment complex and where the women cleaners take a break are two locations that showcase Fassbinder's awareness in creating an alienating and isolated space. Confined characters that present pain in real time create more of a bleak presentation of how life is in Munich, using time and isolation to re-imagine the melodrama. Emmi's apartment complex is reminiscent of a jail cell, from the outside and the inside. The cold brown walls and the icy-grey blue that we see in the morning against a dark brown exterior presents a forgotten space that still is inhabited by all different types of people. Spacial isolation is a frequent tactic in how to create a stressful and compact way of looking at our subjects and people on film, by compressing and creating rigid space.

Douglas Sirk's use of interiors are incredibly opposite when it comes to looking at how they are used to stage the melodrama. While we see Sirk's artistic eye through the architecture of the home and the lavish and exuberance comes out through the production design and color, Fassbinder still uses color to his advantage but strips everything back, letting these characters suffer and move through cold interiors and emotion-less spaces. Many have looked at Sirk's work and wondered about the artificiality present in his suburban interiors, but the decor reflected the decade. As we look at the interiors of Ali: Fear Eats the Soul, we see bodies restrained from any type of response when in groups of five or more and the setting allows for alienation and isolation to breathe true in unwelcoming spaces.

\section{Far From Heaven}

Douglas Muzzio and Thomas Halper, in their essay Pleasantville? The suburb and its representation in American movies, offers three ways to read a film for the audiences at home. The first discusses the content of the film, from the images, sound and the relationship between both. The second are the intentions of the filmmakers (especially the director's), but the intentions are different from motives. Muzzio and Halper say that: 
"Intention showcases the filmmaker's aesthetic and political notion of how to orchestrate the film that they want. Motive discusses the desire for profit for the film, even if the film is bad or just not good. Intentions also direct questions, such as what were the filmmakers seeking to convey, and what influences shaped their intentions? (these influences stem from personal ideological, institutional, etc" (545)). The third is the audience's reading of the film.

"Movies must be analyzed with reference to both their surface content and their deeper implied meanings. A movie must be considered in relation to the specific conditions that led to its production, the broader social and political context from which it sprung, and the audience for which it was produced" (545). In Todd Haynes' film Far From Heaven, we are able to see how he changes the narrative, even if the storyline from Sirk is still prevalent. Haynes' film, while made in the 2000s, still uses all the specifics that Sirk uses like lighting cues and the differences of social class. Haynes' telling of the story gets deeper by letting the characters react to each other through the use of the camera. Far From Heaven becomes even richer by deconstructing the past and the ugly truths that once were societal norms. We also can see the differences a film provides to us when not presented as a melodrama. Haynes uses all the components from the genre of melodrama but lets his films live on as period-piece dramas, and this is done through re-distributing the music cues and how Haynes uses his actors to emote their emotions.

The 1950s become a staple in Haynes' work and his work challenges the audiences to be more aware of the politics and societal problems that were apparent in this time period. Todd Haynes' take on the 1955 film by Sirk allows for the acknowledgment of new social taboos, creating a challenge that our protagonist Cathy is bombarded with. The different social and political ideals that Haynes addresses in Far From Heaven concern race and homosexuality, reworking the Sirk storyline that focuses on small-town gossip and class. Haynes shifts the perspective by creating a deeper dimension of both the romanticized 1950s admiration and the societal suffering that many people faced during this decade. Cathy and Frank are husband and wife in 1950s Hartford, Connecticut, where the picturesque family is shown in a lavish warm musical interlude at the beginning of the film. The nod to Sirk and other melodrama films of the 1950s always shows the artificial before devastation and sadness loom over the family in crisis. Cathy, a homemaker, presents a perfect caricature to her husband co-workers, her friends and others neighbors yet the struggle to blend in with the families in the neighborhood relies on outlier characters to pull Cathy out from her home and into the real world. Cathy, while being a homemaker, finds lots to do in her neighborhood and for her family, but deep down she is looking for a stronger connection. Cathy is looking for someone to understand the stressors that occur within her life and Raymond Deagan becomes the person who listens. Cathy and Raymond's relationship is never sexually intimate, but centered on a kinship of understanding differences that they both witness in Hartford.

In one scene, Raymond brings Cathy to his neighborhood and we see Cathy facing segregation for the first time in her life; this feeling ends up displacing Cathy instead of Raymond. Raymond brings her to a bar known for serving African American men and women. The crowd shows their annoyance to Raymond about bringing a white woman into their establishment. Cathy sees the prejudgement first-hand, while Raymond lets 
the few people who speak up know that everything is cool and they will have a drink and leave. Cathy's whiteness becomes a target, much like how other African Americans were treated in the twentieth century. Cathy and Raymond again experience racism when Cathy tells Raymond to meet her at a diner-style restaurant. Their meeting is interrupted by the clerk behind the bar, who asks them 'Is there something I can do for you folks?" implying that the patrons wouldn't be comfortable until they both leave. Haynes provides two-forms of intolerance for the audience, acknowledging that both Cathy and Raymond could become alienated because of their kinship and tolerance for the differences that they admire in each other. The African American establishment let them be together and share their moment in peace, yet the white establishment makes a point that they would never get service because of Raymond.

We see alienation happening throughout Far From Heaven including at the modern art show and the cocktail party that Cathy throws for Frank's work colleagues. The art show scene showcases an idea of outward looking, seen in Cathy's dialogue to Raymond as they talk about the abstract painting by Mira. When Raymond asks for her opinion on modern art, Cathy responds: "I...just know what I care for, and what I don't". All eyes are on Cathy as she talks to Raymond and the cut away after Cathy finishes her line shows four white upper-class people gawking at them both. The four people that cackle possess the power because they are directing their point of sight towards the outcasts and the outliers in the room, presenting a reason for the audience to stop and stare with the collective white people. Cathy, a white suburban mother of two, is more progressive than the other four people. Cathy's unprejudiced viewpoint allows for her heart to be open, understanding the human connection versus judging someone on their skin tone. Cathy knows what she is doing yet her white suburban affluent 'friends' are shocked that she would put herself in this position not just once, but other times throughout the film. The following scene shows Cathy in her suburban home hosting a cocktail party for her husband's co-workers and friends in the community. While dealing with her husband Frank's own personal issues of homosexual urges and going to see a therapist, Cathy still has to play hostess and happy homemaker to all of her guests even when Frank gets drunk to cope with everything that he is dealing with. One guest brings up the fact that Hartford has some pro-integration types in town. The article that was written about Cathy as the perfect homemaker comments on her affection for everyone, including the African American that showed up in Cathy's backyard. Cathy, while taken aback, shrugs off the remark. Another guest says Hartford doesn't have Negros, so there is no worry of integration. The camera pans on an African American man who is part of the wait staff. This creates another moment of alienation in the crowd, as it seems the article detaches Cathy from her affluent, intolerant neighbors and others at the party. Acknowledging the only African American person in the shot-reverse shot during this scene presents a level of complex alienation that even the audience picks up when watching. Todd Haynes' perspective when showcasing tension lies within how the camera focuses in on the actors/people on screen. Haynes' previous work in Poison (1991) is reminiscent of how he re-created a 50's style b-movie about the horrors of contact with a disease that transformed a man into a monster. The panic that lies within each person this scientist comes in contact with shows the horror that audiences might remember from other 
b-movies of the decade. Haynes uses this panic technique in Far From Heaven several times but it is most prevalent in the scene where Cathy must stop seeing Raymond. This slanted-panic angle is used in the town square section of the film where Cathy has to say good bye to Raymond and Raymond reaches out and grabs her arm not wanting to her go, leaving him alone in this sea of whiteness. The crowd responds to Raymond's action with disgust, anger and shock. The panic is visible through how the crowd responds to Raymond not letting go. A man across the street watches every move that Raymond makes and becomes threatening towards both Raymond and Cathy. Cathy tells Raymond that she cannot stay and leaves Raymond by himself alone next to the movie theatre. The alienation that becomes apparent in both Cathy and Raymond soon fractures the relationship and isolates Cathy even more. The detachment from society is strong here when we add in race politics into the scene, it appears that Cathy might be attacked by Raymond (or at least, that is how the townspeople react to such a situation).

The difference between Sirk and Haynes' telling of the story is that the acting does not have any musical accompaniment letting the acting alone set the tone. The acting keeps the audience engaged without the distraction of an added layer of music. In Far From Heaven, the actors become raw and emotional with no musical interludes when the crisis unfolds. Sirk's melodramatic films of the 1950s play up the camp factor using heavy orchestration alerting the audience to respond to the acting and the emotional turmoil that all these characters are going through. Haynes' approach to the Sirkian melodrama appears in three separate scenes between Cathy and Frank. The scenes have no musical accompaniment allowing for the two actors to have full emotional range. Each scene has to do with the storyline of Cathy dealing with Frank's homosexual urges. The first scene happens when Frank comes home after Cathy walks in on Frank kissing another man in his office. Cathy is seen in the living room, ruminating in a sea of shadows and violet blue light. Reminiscent of Douglas Sirk, but we don't see a true re-telling of Sirk's story. What we get is a whole new way of looking at Sirk's work. By letting the scene play out between Cathy and Frank, we lose the camp factor that Douglas Sirk used to pull at the audiences' heartstrings. Haynes lets his audience feel for the characters on screen without melodramatic music in the background.

Far From Heaven allows for the emotion of a failing marriage to take flight, and we see this when Frank and Cathy are together in the living room. The second time they are together shows Cathy picking up after they both hosted a cocktail party. Frank has had a lot to drink and he sits and stews in his chair. When Cathy approaches him, his kisses become almost monstrous, and he hovers over her like Frankenstein with his latest victim. His kisses turn to passion but he is impotent and he starts to cry on top of Cathy. While he has been getting therapy for his sexual urges, we see this scene as a wake up call that even alcohol cannot muster up feelings he does not have and there is no reason to keep up the charade. Cathy says it is all right and tries to console Frank, but Frank becomes angry with himself and strikes Cathy across the face. Cathy, shaken up, asks Frank to go get her some ice for her face. Frank, coming to from a hazy buzzed state is disgusted with himself that he would strike his wife and is in shock when leaving the living room. Cathy realizes that all of her love and attention is not working. 
The third time we see Frank and Cathy in the living room is later on in the film when they have come back from their trip to Miami. A younger male had glanced at Frank during the New Year Eve soirée that was happening in the hotel they both were staying at. Frank ends up leaving the pool to grab a magazine for Cathy and a newspaper for him, and once Frank is in his hotel room, he sees a young male reflected in the vanity mirror. Draped only in a terry-cloth bathrobe, both men look at each other with lust and longing. Frank admits he has had an affair and Cathy stands in disbelief. She had hoped that it had not come to this, but Cathy in a quiet but certain tone understands that she will need to become a divorcée. What shocks Cathy is that Frank says that he feels love for the first time in his life. Cathy feels as if she has been with a stranger all this time.

The necessary need to dive into these scenes is because we see the emotion as pure, genuine and heartbreaking. If we felt for anyone in the scene, it would be for Cathy. Cathy is strong in that she is capable of doing things in the home much like Cary does at the start of All That Heaven Allows. If Douglas Sirk were to re-shoot the scenes with Frank and Cathy, there would be much more camp factor to the heartbreak and devastation. Cathy has been the one keeping the whole house in order and keeping all things sane but now with no man in her life, it affects her but does not break her. We don't see her declaring a need to be with Raymond until she runs out of her house after hearing what had happened to his little girl. This creates a divide for Cathy and Raymond's storyline after she leaves Raymond's home. Cathy has nowhere to turn and once she realizes that she will have to move on, the emptiness and sadness becomes a reality for Cathy.

\section{The Melodrama in Popular Culture}

In the book Melodrama: Genre, Style, Sensibility by John Mercer and Martin Shingler, they write: "Melodrama, like film noir, is a critical category that emerges as a consequence of the identification of a range of films which use the family and social position of women as their narrative focus" (2). The family often is in crisis, and we see this as a prompt for cinema to keep on producing films that alter the trope of the picture-perfect family. We see this done by Nicholas Ray in his films Bigger Than Life and Rebel Without A Cause. Directors from the 1950's into the present day are using the stylistic choices that the melodrama offers. The Sirkian melodrama re-establishes its moment in cinema by Spanish director Pedro Almodovar whose women-centered films offer different cinematic stories presenting LGBT and trans storylines to be part of the discussion. The practicality of the melodrama ever leaving the popular culture canon relies solely on the audience and what appeals to them, to what society and the audience consume. Soap operas were once a huge money maker in American television, but now have become a hybrid merging what the melodrama offered to audiences at the cinema to what the family drama offers to prime-time audiences around the television set. These hybrids of melodrama and family dramas might only last for one season if the audience does not find something to sink its proverbial teeth into. 
Melodrama's, much like radio serials of the 1930s, still rely on an audience to be captivated by what has happened in the ever-growing story arc. You can see this in Rainer Werner Fassbinder's 1972 television series Eight Hours Don't Make a Day, pitched to Fassbinder as a family series for German network Westdeutscher Rundfunk. Story arcs presented in melodramas from the past are current in today's market as well, as we have seen in soap operas like The Young and the Restless and even the Canadian pre-teen drama Degrassi, that lasted over fifteen years on television before moving to digital streaming on Netflix. In the chapter entitled Notes on Sirk and Melodrama, Laura Mulvey writes: "While the Western and the Gangster film celebrate the ups and downs endured by men of action, the melodramas of Douglas Sirk ... act as a corrective"(39), simply put that Sirk's position of power allows for him to help the audience identify with the female protagonist in his film. Douglas Sirk's work with Universal Pictures (1952-1959) which includes Magnificent Obsession (1954), All That Heaven Allows (1955), Written On The Wind (1956), Battle Hymm (1957), The Tarnished Angels (1957), Interlude (1957), A Time to Love and A Time to Die (1958), and Imitation of Life (1959) allows this section of his film work to present post-war luxury with heightened sadness, understanding the complexities of an everchanging family life.

Sensationalism also is a huge factor in crafting a spectacle on screen for Sirk's audience. Sensationalism can only bring in so much of an audience in the 21st century, yet a show like Degrassi alters the perspective just enough for it to be fresh for its viewers. Degrassi offers the soap opera and melodramatics that we see through the broken family, women and LGBT issues but focuses on the turmoil that each of these students must suffer through while attending high school. The focus on the outcasts throughout the show allows for the melodrama to be ripe for the picking, letting the fourteen to eighteen year old demographic feel for these characters and seeing a bit of themselves within each storyline. Degrassi is a strong outlier that presents the argument that audiences in today's market still want the melodrama on screen, even if it means it's meant for an at-home audience and not in the theatre. Sensationalism also is seen in the way advertising is used in the film posters of the day. Eye-catching italicized words and emotional language presented in the marketing lure people into the cinema, through the construction of the trailer or through the marketing on the posters and lobby cards.

\section{Conclusion}

In Douglas Sirk movies, women think. I haven't noticed that with any other director. Usually the women just react, do the things women do, and here they actually think. There's something you've just got to see. It's wonderful to see a woman thinking. That gives you hope. 
The work that came from Douglas Sirk during his Universal Pictures contract has become an important timepiece in cinema's rich history. Time Magazine said about All That Heaven Allows: "the characters all talk Ladies Home Journalese, and the screen glows like a page from House Beautiful" (171, Artforum Magazine). That being said, the 1950s melodrama has been elevated through the gaze and creative juices of Douglas Sirk that offers so much to the audience. The female in Sirk's films are women who look at the problems head on and stand their ground finding their voice and independence through hard times or moments of change. Feminist film theorist Laura Mulvey is an important voice in understanding the Hollywood films of the 1950s. Mulvey makes us re-look at Fassbinder's approach towards the film and the 1950s Hollywood system. Mulvey writes: "Fassbinder's films are not specifically feminist but they are of interest to women because they deal consistently with themes in which women have an independent importance, and have been emphasized by the women's movement: the family, hysteria, and the contradictions between the oppressed and the oppressor within a class" (45). Mulvey wants to make it clear that while Fassbinder's approach is not truly feminist cinema as a whole, what Fassbinder provides to the viewer at home is a sense of community by not crafting a farce or malice towards the American melodrama. Fassbinder creates stories that provide our female protagonists with weight and perseverance to move through these cinematic stories. Using the film that Fassbinder created, we see how Emmi soon re-examines her way of living in order to incorporate Ali into her home.

J. Hoberman, in the article Pop Before Pop: Welles, Sirk, Hitchcock states that "The idea of Sirk-the notion of an artist grasping at the aesthetic possibilities provided by the studio system and commercial-genre conventions-is as seductive as his movies, made for the masses as well as for an audience of one" (172). The melodrama seems to be a genre that audiences still flock to, though the idea that cinematic artists would return to the Sirkartform still needs to be fleshed out. Can the American melodrama of the 1950s, the films that brought Douglas Sirk back to relevance, still thrive for years to come? And how can the female protagonist of yesteryear survive in film, or has the melodrama once thriving on radio and television shifted into the world of streaming? Do we see a resurgence of melodramatic film coming in the future, or will it soon fade to black?

\section{Bibliography}

Fassbinder, Rainer Werner, Director (2014). Ali: Fear Eats the Soul. Criterion Collection. Haynes, Todd, Director (2019). Far From Heaven. Universal Studios, Focus Features, Kino Lorber.

Klinger, Barbara (1999). Melodrama and Meaning: History, Culture, and the Films of Douglas Sirk. NetLibrary, Inc.

Mulvey, Laura (1989). Visual and Other Pleasures. Houndmills, Basingstoke, Hampshire: Macmillan, Print.

Muzzio, Douglas and Halper, Thomas. "Pleasantville?: The Suburb and Its Representation in American Movies." Urban Aires Review 2002, http://uar.sagepub.com/content/37/4/543 
Peacock, Steven (2010). Colour, Manchester University Press.

Reimer, Robert Charles, et al. (2017). German Culture through Film: an Introduction to German Cinema. Focus Publishing/R Pullins \& Co.

Sirk, Douglas, director (2019). All That Heaven Allows. Universal International Pictures, The Criterion Collection.

"Visual Pleasure at 40: Laura Mulvey in discussion (extract) | BFI." Online video clip. YouTube. YouTube. May 29th, 2015. Web. 5th May 2020.

Centrándonos en la protagonista mujer de las películas: All That Heaven Allows de Douglas Sirk, Ali: Fear Eats the Soul de Rainer Werner Fassbinder y Far From Heaven de Todd Haynes

Resumen: Cuando se vuelve a hacer una película, la historia principal cambia para reflejar las normas sociales de una nueva audiencia. Ali: Fear Eats the Soul (1974) y Far From Heaven (2002) son réplicas de la película original All That Heaven Allows de 1955. Cada película aborda diferentes problemas con la mujer como protagonista. La clase social, la raza y la homosexualidad son el núcleo de estas tres películas. En este artículo, discutiré las tres películas e intercalaré cómo la heroína se descubre a sí misma y porqué necesita evolucionar. A medida que cada heroína se encuentra a sí misma, se esfuerza por romper la monotonía que la sociedad ha construido para ella, y al liberarse descubre lo que ha estado buscando en sus propios términos. Las estructuras sociales obstaculizan a nuestra protagonista al crear barreras para que se supere, como las diferencias de clase, la intolerancia racial y el amor. El periplo de la mujer se analizará a través de un enfoque crítico de cada película, incluido su diseño de producción, música e iluminación. La teoría feminista del cine nos ayudará a entender cómo cada generación ve a los personajes femeninos en la película. En la próxima década, esta película podrá contarse a través de un filtro completamente diferente basado en las normas sociales a las cuales se enfrenta esa generación.

Palabras clave: Melodrama - película - protagonista femenina - crítica de cine - Laura Mulvey - Douglas Sirk - Rainer Werner Fassbinder - Todd Haynes.

Focando a liderança feminina nos filmes: Tudo o que o céu permite de Douglas Sirk, Ali: $O$ medo come a alma de Rainer Werner Fassbinder e Longe do céu de Todd Haynes

Resumo: Quando um filme é feito novamente, a história principal muda para refletir as normas sociais de um novo público. Ali: Fear Eats the Soul (1974) e Far From Heaven (2002) são réplicas do filme original All That Heaven Allows, de 1955. Cada filme aborda diferentes problemas com as mulheres como protagonistas. Classe social, raça e homossexualidade estão no centro desses três filmes. Neste artigo, discutirei os três filmes e mostrarei como a heroína se descobre e por que ela precisa evoluir. À medida 
que cada heroína se encontra a si misma, ela se esforça para quebrar a monotonia que a sociedade construiu para ela e, libertando-se, descobre o que estava procurando nos seus próprios termos. As estruturas sociais atrapalham nossa protagonista, criando barreiras a serem superadas, como diferenças de classe, intolerância racial e amor. A jornada da mulher será pesquisada através de uma análise crítica de cada filme, incluindo design de produção, música e iluminação. A teoria feminista do cinema nos ajudará a entender como cada geração vê personagens femininas no filme. Na próxima década, este filme pode ser contado através de um filtro completamente diferente, com base nas normas sociais que a geração está enfrentando.

Palavras chave: melodrama - filme - protagonista feminina - crítica de cinema - Laura Mulvey - Douglas Sirk - Rainer Werner Fassbinder - Todd Haynes.

[Las traducciones de los abstracts fueron supervisadas por el autor de cada artículo] 